Man and Nature

L'homme et la nature

\title{
Bernard Bosanquet and the Development of Rousseau's Idea of the General Will
}

\section{William Sweet}

Volume 10, 1991

URI : https://id.erudit.org/iderudit/1012634ar

DOI : https://doi.org/10.7202/1012634ar

Aller au sommaire du numéro

Éditeur(s)

Canadian Society for Eighteenth-Century Studies / Société canadienne d'étude du dix-huitième siècle

ISSN

0824-3298 (imprimé)

1927-8810 (numérique)

Découvrir la revue

Citer cet article

Sweet, W. (1991). Bernard Bosanquet and the Development of Rousseau's Idea of the General Will. Man and Nature / L'homme et la nature, 10, 179-197. https://doi.org/10.7202/1012634ar

Copyright (C Canadian Society for Eighteenth-Century Studies / Sociéte canadienne d'étude du dix-huitième siècle, 1991
Ce document est protégé par la loi sur le droit d'auteur. L'utilisation des services d'Érudit (y compris la reproduction) est assujettie à sa politique d'utilisation que vous pouvez consulter en ligne.

https://apropos.erudit.org/fr/usagers/politique-dutilisation/ 


\section{Bernard Bosanquet and the Development of Rousseau's Idea of the General Will}

It would be no exaggeration to say that one of the most developed statements of idealist political thought can be found in the work of the English philosopher and social reformer, Bernard Bosanquet. Bosanquet's project was to account for political liberty, the binding force of the law, and the function, duty, and rights of the individual within a state. Although his political writings date from the last decade of the 19th to the middle of the third decade of 20th century, they are clearly influenced by the philosophy of the Enlightenment. And, like so many of these philosophers, Bosanquet argued that not only is the principle of might or force clearly insufficient to provide such an account, but one must also go beyond the presuppositions of the kind of liberal individualism that one finds in Hobbes and Locke and, later, in Bentham, Spencer, and Mill. Bosanquet's alternative was to turn to what he called the 'general' or 'real' will.'

Bosanquet acknowledges that this principle finds its initial articulation in Hobbes and Locke, but insists that it is only with its transformation by Rousseau that it begins to acquire its full explanatory character (cf. IPR 323). He believes that, by means of the idea of the general will, Rousseau provides a new way of understanding the notion of sovereignty and the basis of political liberty and, hence, shows how to justify existing institutions, man's relation to the state, and his social obligations. ${ }^{2}$ Indeed, Bosanquet claims that it is the principle that 'Will, and not force, is the basis of the State, ${ }^{3}$ which is the foundation of modern political philosophy (IPR 323; 329).

One might well ask, then, what the relation is between Rousseau's idea of the general will and that used later by Bosanquet. Are they the same, is Bosanquet's use of the notion a logical extension of the principles that Rousseau himself provides or is the similarity more apparent than real? Over the next few pages, I will examine Rousseau's account and discuss some of the ways in which Bosanquet understood, criticized, and developed this treatment of the general will. 
It is primarily in the Contrat Social ${ }^{4}$ that Rousseau explains and discusses the notion of the 'general will,' but even there the account given is, at times, quite obscure. While Rousseau lists a number of the characteristics of the general will and explicitly distinguishes it from related concepts, he never clearly defines it. The reader is told, for example, that when the individual takes part in the social pact, he puts himself under the direction of the general will. This will aims at (CS II.3) and reflects a common interest (CS II.4, p. 69), and it alone may direct the state. It is 'changeless, incorruptible, and pure' (CS IV.1); it is 'toujours droite' (CS II.3) and rules when the passions are silent. The general will is found when agreement reigns in an assembly (CS IV.2, p. 147), although it is neither a sum of particular interests or particular wills, nor the will of the majority as such, nor even 'the will of all' (CS II.3). Even though Rousseau provides his readers with some suggestion on how they may discern the general will, he says little more about its nature than what has been cited above.

'How,' Rousseau's reader might ask, 'is the general will "general"?' Rousseau alludes to several characteristics, of which four seem particularly relevant here: the general will is general in origin, in scope, in form and in object. Since this will comes from everyone in a specific group, one can say that it is general in origin, and it is for this reason that its actions are general in scope - that is, are genuinely authoritative on these individuals (CS II.2; II.4). ${ }^{5}$ The general will is general in form in the sense that it has nothing particular or distinctly individual about it. (Rousseau is especially emphatic that it not be just someone's 'particular will' - 'une volonté particulière' (CS II.4, p. 69).) Rousseau describes the general will as the product, though not the sum, of all the individual wills in a community, after the 'pluses' and the 'minuses' that distinguish these wills have been eliminated (CS II.3). Finally, the general will has as its goal - and this seems to be crucial - an object which is itself general: the 'universal interests of Society' (IPR 333), the common good or interest of all of the individual wills (CS IV.1; II.3; II.4, p. 69). ${ }^{6}$

The 'general' character of this will is contrasted by Rousseau with a prima facie similar notion, which he calls 'the will of all.' Like the general will, the will of all has its origin in the individuals who together constitute the social group. Its object, however, is not general, but is essentially a private interest. Even if many or all of the citizens should concur about what is to be done in some specific case, each has his own reasons or motives, and there is nothing beyond the present accord to suggest that this association is anything more than accidental. The will of all is not, therefore, general in form; it reflects only the domination of one private 
interest amid a multiplicity of essentially discrete and independent individuals. Finally, lacking generality in object and form, there is no basis on which the 'will of all' can make a legitimate claim to the obedience of these individuals; hence, it is not general in scope.

Rousseau claims that only his notion of the general will can explain the legitimacy of social or political authority or, what amounts to the same thing, provide the basis of social and political obligation. In his view, the only real authority over an individual is the individual himself, ${ }^{7}$ and society has a legitimate claim on him, therefore, only when it is, or reflects, his will.

On the analysis given above, the general will is the will, 'generalized,' of each and every one of the members of a specific group. Such a will has its origin in the individual, and Rousseau adds that this generalized will is a part of, and exists in him: 'Chaque individu a une volonté générale comme citoyen' (CS IV.1, p. 146; see II.2, p. 149f). One is obliged to obey the general will, therefore, because it is essentially one's own will. In this way, moral obligation makes sense, for it is not a question of some purely external force obliging the individual to act, but rather of the 'general will' in each person asserting its authority over his particular will. Similarly, so far as the state or sovereign represents the general will, one is obliged to obey it. Consequently, we can see how the idea of the general will allows Rousseau to account for political obligation, or speak of the individual legitimately being 'forced to be free.' It is a corollary of this, moreover, that when the 'will' (that one finds, for example, expressed by the sovereign of Hobbes's 'commonwealth') is not general in form and in object, it cannot provide an adequate basis for genuine moral or political obligation.

II

It is from such an account of Rousseau's notion of the general will that Bosanquet's discussion begins - although he would point out that much more can be said about this will. How much more can actually be found in Rousseau is not easy to determine. Given the apparent similarity of many of Rousseau's ideas to his own, Bosanquet's account of Rousseau has sometimes been challenged as reading into the Contrat Social statements that its author never intended. ${ }^{8}$ To be sure, Rousseau is far from complete in his description of the general will and one understands that, as a philosopher, Bosanquet may well adapt Rousseau's insights to his own particular purposes. Still, upon examination, it would seem that the views which Bosanquet ascribes to Rousseau do not stray far, if at all, from the latter's text. 
Take, for example, Bosanquet's claim that it is by the mechanism of the general will that Rousseau is able to overcome the negative relationship that many individualists saw (and see) between the individual on the one hand, and law and government on the other (PTS 95). Rousseau does not explicitly discuss this, and yet it would seem that Bosanquet is correct in attributing such a view to him, based on the latter's account of the general will and its role in political obligation. Law and the state, in principle, reflect a will that is, ultimately, the will of the citizen, and hence there is no a priori antagonism between the two.

Another instance, where the accuracy of Bosanquet's treatment of Rousseau is perhaps more controversial, concerns the question of whether Rousseau believes that the general will 'actually exists.' What it means for something to 'actually exist' is rather vague, and the options here seem to be limited to, on the one hand, the general will being something 'independently existing' and 'transcendent' and, on the other, it being merely an attribute of a sort of legal person, the state an entity which itself exists only by some artificial convention and which has no existence apart from, or over and above, such an agreement.

Bosanquet recognizes that 'what Rousseau means to indicate by his expression "the general will" may seem to many persons... to have no actual existence' (PTS 99). Some recent commentators suggest just this. They claim that any other reading of the concept of the general will or of the allied notion of the 'moral personality of the state' simply goes beyond Rousseau's intention. ${ }^{9}$ Bosanquet believes, however, that while Rousseau may indeed be borrowing such terms as 'moral person' and 'collective body' ('un corps moral et collectif' CS I.6, p. 52) - terms which presumably have the character of 'legal fictions' in Hobbes and Pufendorf - he is giving them a new meaning and a different status (PTS 89; 94; IPR 332). Such a development will, in turn, have implications on the nature of the existence of the general will. But is Bosanquet reading too much into Rousseau's text? ${ }^{10}$

The possibility of development in the notion of 'moral person' seems supported by the fact that there is already clearly a change in another concept that Rousseau borrows from his predecessors - that of the social contract. Moreover, since Rousseau says that the act of association creates a moral person (the state) which has 'unity,' a 'common self,' a 'life' and a 'will' (CS I.6), it would appear that he has something in mind that is more than a legal person (PTS 89, n. 1) or something formal and artificial. In fact, were this not so, what could Rousseau possibly mean when he speaks of a 'common self,' or how could the state have a 'life' and a 'will' which is no particular individual's will? Finally, Bosanquet believes that Rousseau's general will must have more than a formal and conventional or artificial character if the use of 
force against the physical individual is to be legitimate. This will must be a substantively common will, which is the real will of the individual. Bosanquet concludes that for Rousseau the general will is not just a characteristic of a legal fiction.

What, then, does Bosanquet mean by the 'actual existence' of the general will in Rousseau? He does not claim that Rousseau considers the general will to be merely the decision-making function of the (legitimate) state or a characteristic expression of its authority. The general will is the directing principle of the state, but has its existence independent of it. If the 'contractants,' in the act of association, put themselves 'under the supreme control of the general will' (CS I.6, p. 52), it would seem that the general will is something more than the will of the state and is (at least logically) antecedent to it.

Rousseau is not here claiming, however, that this will is an entity that exists separately from both the state and human individuals. Instead, to use a phrase that Bosanquet employs in the elaboration of his own view, the general will exists as an 'idea force.' One may, for example, speak of the reality or actual existence of the idea of democracy in a nation and in its citizens, without claiming that this idea exists as some transcendent entity or being. Such an understanding of the actual existence of the general will, then, seems to be consistent with what Rousseau had in mind when he wrote, as noted earlier, that the general will is in both the (legitimate) state and in each individual as a citizen. ${ }^{11}$

One may ask, of course, what it means for something to be in the state or in individuals, and yet in some way distinct from both. It seems to Bosanquet that Rousseau must, therefore, 'insist on the higher reality of something that is not a visible human individual, but which is the spirit or the thinking underlying a body of individuals, so that a will which is both positive and general may be able to be conceived' (IPR 332-333). ${ }^{12}$ Admittedly, this latter phrase is not Rousseau's. But even to admit that the general will is 'transcendent' (PTS 100) is not to say that it is some kind of hypostasized entity. Thus, while Rousseau does not spell out what is meant by the existence of the general will, Bosanquet would argue that this explanation is simply the consequence of what Rousseau himself says in the Contrat Social.

There are, of course, other questions that one might raise about this concept of the general will. As Bosanquet himself asks, 'how can anything be my Will which I am not fully aware of, or which I am even adverse to?' (PTS 110). But Bosanquet's interest in Rousseau's analysis of the general will was primarily to show the advance that it represents in the history of political thought, and to use it as a basis from which to introduce his own theory. His criticisms are, therefore, relatively few. Still, even if Bosanquet was not particularly interested in constructing 
a critique of Rousseau, it is only by looking at the criticisms he does make that one can have a deeper insight into how he develops Rousseau's views.

III

Bosanquet's principal criticisms of Rousseau's account suggest that it is not yet entirely free of elements characteristic of liberal individualism - what Bosanquet calls 'theories of the first look.' Specifically, he attributes many of the inconsistencies in Rousseau to his use of an inherited vocabulary (PTS 85). One such example occurs in Rousseau's discussion of capital punishment. Rousseau seems to argue that such punishment is justified because, among other reasons, the subject has transferred to the sovereign a right over his body (CS II.5, p. 71). ${ }^{13}$ Yet it is clear that this notion of surrendering 'some part of a previous freedom in order to make the most of the remainder' (PTS 84) is quite foreign to the character of Rousseau's social pact, and Rousseau in fact denies that individuals renounce anything when they enter into the social contract (CS II.4, p. 70). Again, Rousseau frequently refers to the right of the first occupant (CS I.8) or to one's rights anterior to the social pact, and yet he also argues that the condition where such 'rights' putatively exist could not, in fact, recognize or support them (CS I.9).

In some cases, however, inconsistencies and other problems arisedue not so much to the infelicitous use of a term, but to a problem in the analysis or the method Rousseau employs. Specifically, Bosanquet charges that Rousseau fails to maintain the distinction between the general will and the will of all. He claims, moreover, that Rousseau's theory is not only unworkable (PTS 99; 'inapplicable' IPR 335), but incompatible with its avowed aim. Finally, Bosanquet believes that Rousseau's method of determining the general will exhibits a defective view of social life.

Rousseau's distinction between the general will and the will of all, Bosanquet says, is clear in principle. In the former, each person is moved by his own particular motives; in the latter, it is the 'community of public interest' that moves him. Bosanquet objects, however, that in making this distinction, Rousseau sets a problem to which he 'scarcely finds an answer' (RGW 308), and that the method Rousseau uses to identify the general will would end up 'enthroning the Will of All' (PTS 108).

Rousseau believes that the best method of determining the general will is to insist that each person, uncontaminated by external influences, decide what he thinks it is (CS II.3). Thus, each citizen must 'vote,' independent of the activity of organizations or parties and independent 
of the exchange of information or of personal convictions. Bosanquet would object, however, that in so doing, Rousseau is looking for the general will and the common good, not in the nation as a 'whole' but in an 'aggregate of isolated individuals' (PTS 109). But such a view of the citizen and the state employs the very individualist presuppositions that Rousseau explicitly rejects. Moreover, Bosanquet claims, this method would virtually ensure that the 'will of all' become dominant - which is precisely the opposite of Rousseau's professed aim. Rousseau's approach, therefore, seems to lead to an inconsistency in his work. ${ }^{14}$

Bosanquet also argues that Rousseau's procedure does not pay due attention to the general will as a 'system in motion' (RGW 314) which 'always needs the future to explain its real tendency' (RGW 317). For a vote to be a genuine indication or expression of the general will, it 'needs interpretation in order to say what direction of movement' the will is going in (RGW 314). It cannot supply this 'interpretation' itself, and can show no more than de facto tendencies (RGW 315). ${ }^{15}$ In short, Bosanquet believes that Rousseau's method leads one to see the general will as something static and complete, rather than as a process. ${ }^{16}$

If the general will cannot be ascertained by such a 'free vote,' how can one discern what it is? Bosanquet believes that a more adequate answer is suggested elsewhere in Rousseau's text.

In a rather mythic section of the Contrat Social, Rousseau states that the legislator has the task of discovering the general will and of teaching it to the people. Rousseau's legislator functions as a sort of 'midwife' for the social mind. ${ }^{17}$ Bosanquet would add - though he recognizes that Rousseau would disavow such an interpretation ${ }^{18}$ - that the legislator, in his capacity as representative of the people, then has the right and the duty of incorporating this will in the law, in conformity with the public good. He believes that it is in exactly this way that the authors of at least two of the French declarations of rights - those of 1789 and of 5 fructidor, an III (22 August 1795) - saw the role of the legislator (IPR 335 , and note 3 ). In fact, Bosanquet adds that this activity also describes the role of representatives in the legislature of a modern constitutional state. Rousseau's 'suggestive' remarks on the legislator, Bosanquet would maintain, supply a more productive means for discerning the general will than do his explicit comments on the subject. By not exploring these remarks, he continues, 'Rousseau failed to be true to his own best insight' (PTS 99).

It is not, however, simply because of problems with the determination of the general will that Bosanquet finds Rousseau's theory impractical and unworkable. Nor is it a question of the improbability or difficulty of getting unanimity to establish a law. It is simply that such a theory would not be 'adequate to the action of a very complex society with 
elaborate constructive tasks before it' (RGW 309) and, indeed, would be inconsistent with the very principles of modern democratic states.

To begin with, Rousseau claims that it is only in small groups that the general will can be expressed, laws derived and sovereignty exercised according to the method he proposes (CS II.4 and IV.2). The models he has in mind are Athens and Sparta and, in his own time, the cantons of Switzerland (IPR 335). Bosanquet replies, however, that the actual functioning of a state - even a very small one - is much more complex than Rousseau imagines, and that it is doubtful that such a procedure would ever work (PTS 99).

The more telling criticism that Bosanquet raises, however, is that Rousseau's account is, once again, inconsistent. According to Bosanquet, Rousseau wishes to provide not only a new theory of the state but also an account of how one can justify or legitimate existing political institutions. ${ }^{19}$ He reminds us that Rousseau begins the Contrat Social by claiming that he can explain what may legitimate the change from being 'born free' to 'being in chains. ${ }^{20}$ In principle, then, the reader would expect a compatibility between the system Rousseau proposes and 'the constitutional and representative organization that is almost universal among modern states' (IPR 335). It is, after all, in these 'chains' or social obligations that Rousseau claims man's equality and liberty are realized.

Yet Rousseau states that acts of sovereignty (i.e., laws) must reflect the general will and the common good. Any law that does not have as its goal the common interest has no authority and is, therefore, invalid. To this, Bosanquet replies that '[n]o political theorist, however visionary, could accept such a conclusion' (PTS 108), and it is clear that no legal system - at least, none of those present in the major European states then or now existing - would, or could, meet this condition. In short, according to Bosanquet, Rousseau's criterion for law is incompatible with that at which he appears to aim - namely, the justification of existing social institutions and the demonstration of how they are necessary to equality and freedom.

Bosanquet's final major criticism of Rousseau is that the method of determining the general will exhibits a defective view of social life. According to Bosanquet, not only are social institutions and the exchange of ideas necessary to determining the general will and the common good of a society, but these very institutions in fact reflect the general will (PTS 114-15).

Social life involves the existence of 'institutions' such as the family, the neighborhood and the social class, as well as interaction within, and among, these various groups. Rousseau fails to see, Bosanquet claims, that the give-and-take among persons that occurs in social life is natural and has an important role in the formulation of the general will. It is 
through the exchange of ideas - replacing bad ideas with better ones, replacing error with truth, seeing one's inconsistencies or limits through contact with others - that one's will becomes more coherent with itself and with that of others and that the general will has a better chance of being made obvious. ${ }^{21}$ The constraints which Rousseau's method of determining the general will imposes, however, are purely artificial and oppose the natural tendencies of society.

But Bosanquet would go further. As individuals act and as they become conscious of the general will, it becomes a principle in their actions and gradually is objectified in social institutions and social practices. An example of this, implicit in Rousseau's work, is the 'institution' of morality. While morality, unlike law, is not codified by the state, Rousseau acknowledges that it exists and develops only within the social interchange present in the civil state (CS I.8), and it gradually becomes objectified in a set of moral practices (e.g., honesty, aid to those in need, self-control, etc.). By failing to see how this process might also apply to social institutions, Rousseau misses an opportunity to provide what Bosanquet would consider to be a more fruitful method of discerning the general will.

It is in light of these criticisms of Rousseau that Bosanquet feels obliged to provide his own account of the idea of the general will. He finds it particularly important to present a more complete explanation of the nature of this will and to emphasize the necessity of social life and of existing social structures. In this respect, his remarks show the influence of Hegel's Philosophy of Right. But it is the idea of the general will that represents, for Bosanquet, a turning point in the development of political thought, and the core of his view lies in the groundwork laid by Rousseau. It should be no surprise, then, that after his discussion of Rousseau's theory, Bosanquet should still be working out of the principles that he found therein.

\section{IV}

Bosanquet rarely discusses the general will without some mention of Rousseau, and often it is difficult to say precisely where exposition and interpretation end and where Bosanquet's own theory begins. Still, given the criticisms of Rousseau noted earlier, one can identify at least some of the principal features of Bosanquet's view: in particular, his 'metaphysical' account of the general will and the function of the state in its elaboration and discernment.

What is the nature of the general will? It is neither a 'legal fiction' nor an 'abbreviation' used to describe a series of empirical entities, nor is it 
merely a way of looking at, or describing metaphorically, certain phenomena. On this, there is no disagreement with Rousseau. But Bosanquet's description of this will goes far beyond that which Rousseau provides. It is, Bosanquet explains, something 'real' and 'rational' that exists at the level of mind or spirit.

The 'metaphysical' character of the general will can be seen in Bosanquet's description of it as 'the whole working system of dominant ideas' in a society (RGW 314). Bosanquet claims that, in society, there is a 'mutual recognition' and interaction of minds or wills which may be said to form a system (NGW 77). But the possibility of even such 'mutual recognition' requires the prior existence of certain dominant ideas such as that of a common good - on the basis of which individuals are able to recognize and establish relations with one another. This 'system' is not the product of a social pact, yet neither is it prior to society in a temporal sense. ${ }^{22}$ It is, rather, logically or ontologically prior to society, for it arises through the extension into the external world of the same logical principles which Bosanquet argues are essential to a coherent inner life or individual will. ${ }^{23}$ For Bosanquet, this general will exists wherever there is some common experience and cooperation (PTS xxix; IPR 334) among persons - that is, the same 'dominant or organizing ideas' (RGW 312-313) and, in particular, the same common good.

Bosanquet's argument for the existence of the general will might be reconstructed as follows. To begin, Bosanquet describes the individual will as 'a mental system' whose parts - 'ideas or groups of ideas' - are 'connected in various degrees, and more or less subordinated to some dominant ideas which, as a rule, dictate the place and importance of the others' (RGW 311). Thus, '[i]n order to obtain a full statement of what we will, what we want at any moment must at least be corrected and amended by what we want at all other moments.' But the process does not stop there. Bosanquet continues: 'this cannot be done without also correcting and amending it so as to harmonise it with what others want, which involves an application of the same process to them' (PTS 111). In other words, if one wishes to arrive at an accurate statement of what his will is, Bosanquet believes that he must be concerned not only with what he wishes at some particular moment, but also with all of the other wants that he does or might have, given all of the knowledge available. Bosanquet describes this 'will,' then, as 'rational' (PTS 139) and, although he often calls it an individual's 'real will,' ${ }^{24}$ 'in some sense, (it) transcends the individual whose will it is' (PTS 100). In fact, one's 'real will' is, Bosanquet says, just another name for the general will.

The general will is, in the end, the 'criticism' or the interpretation of all the particular wills of all the particular individuals in a social group (PTS 111). It is a system of ideas, corrected and modified by reason and 
by all the information available, and so becomes more than any one person's will at any particular moment. There is, Bosanquet would conclude, an unbroken continuum from the individual will considered as a 'mental system,' through its involving others, to the formulation of the general will. ${ }^{25}$

Given this description of Bosanquet's idea of the general will, in what sense and where can it be said to exist? Bosanquet's answer is that the general will - 'the whole working system of dominant ideas' - exists in the same sense in which ideas are said to exist, and it will be found in groups that exhibit a unity in function and in purpose.

To see this point more clearly, one might turn to Bosanquet's comparison, in The Philosophical Theory of the State, between the principles at work in an army and those at work in a crowd. An army may be described, for example, as a multitude of men living under the control of certain 'dominant ideas.' These ideas are incorporated not only in the military hierarchy, but also in the experiences, the training and the habit of obedience of each soldier (PTS 150). Moreover, the relationships that exist among these individuals are not casual or accidental, but are determined by 'the general nature of a systematic group to which they belong' (PTS 151) - that is, by common experience and the ideas that are always present and at work. Thus, even though each soldier may have a distinctive function, may perform different tasks, and may not be aware in what way other soldiers contribute to the aims and objectives of the army, the dominant ideas incorporated in its structure determine the relations of its parts to one another and, consequently, permit a coordination and a division of labour as well as concerted action in the future.

In a crowd - of people going to see a fireworks display, for example - these principles do not exist. Individuals may aim at the same goal, but their association is virtually accidental: there is nothing significant in their natures nor in their experiences which unites them. There is here 'no oneness of life or principle' (PTS 106), and the 'level of intelligence and responsibility (in the crowd) will, as a rule, be extraordinarily low' (PTS 150). Reasoning, criticism and concerted action in the future are, practically speaking, out of the question (PTS 150). Bosanquet does not, of course, mean to deny the existence of some common sentiment or idea underlying their activity, but simply to suggest that what there is does not tell us anything important about the parts. ${ }^{26}$ If the crowd disperses, the individuals 'will not be seriously affected by the separation' (PTS 148).

The difference between these two examples shows, Bosanquet believes, that for there to be activity and life in common and, indeed, for the individual human mind to 'attain its full and proper life,' there must 
be 'a community of minds' or, more properly, 'a community pervaded by a single mind, uttering itself consistently though differently in the life and action of every member of the community' (PTS 6). This mind the general will - exists, then, as the system of dominant ideas at work in a social group. This also tells us where the general will exists. While Bosanquet calls the general will 'the will of society "as such,"' there is, of course, no entity designated by the term 'society.' The general will exists, rather, where the dominant ideas of any society exist - namely, 'only in the minds of the human individuals who make up the community' (RGW 309).

It is in this way, then, that Bosanquet will say that the general will exists on the level of mind - a matter which, for whatever reason, Rousseau did not discuss. And it is in this sense that one may maintain that Bosanquet's account of the nature of the general will is more explicitly metaphysical than that of Rousseau.

This 'metaphysical' account of the nature of the general will might lead one to ask in what sense these 'dominant ideas' can be described as legitimately constituting a 'will.' Admittedly, the notion of 'will' that Bosanquet employs when talking about the general will is clearly not identical to that of the will (qua 'voluntas') of the individual. Why, then, call the general will a 'will' at all?

The most likely reason why Bosanquet does this is that he saw what he called the general will as being inspired by, and performing the same function as, Rousseau's 'general will.' Following Rousseau, there is what one might call the 'general will tradition' - a tradition which includes Kant, Hegel, and T.H. Green - and it is clear that Bosanquet sees himself as working within that tradition. Moreover, what Bosanquet designates by the term 'general will' is clearly general and it purports to reflect something akin to the mind or will of the individual. For example, one instance of a 'dominant idea' that Bosanquet might see as part of the general will of most modern states (and of their citizens) is the idea of democracy. Of course, the general will or the state does not 'will' democracy as an individual might 'will' that he do a good deed. Nevertheless, the idea of democracy has an important role in such societies and is 'imperative' on their members. It is a principle of, and guides them in, their action and is like the command of a voluntas. Finally, given that civil society is considered by Bosanquet as a 'moral person' (PTS 145), and since the will is the characteristic of a person that expresses the direction of his actions, society can be said to possess a will. One cannot deny that the use of the expression 'general will' has been in some way responsible for much misunderstanding of British idealism and of Bosanquet in particular. But the general will is not, nor was it ever claimed by Bosanquet to be, a 'faculty' of an individual or of a state. 
A second distinctive feature of Bosanquet's account of the general will in which he develops Rousseau's insights is the method Bosanquet uses to identify this will. This feature is particularly important in view of the more explicitly 'metaphysical' understanding that Bosanquet has of the general will.

One will recall Rousseau's insistence that, in order to ascertain what the general will is, all citizens must 'vote as independent units, not organizing themselves in groups or adjusting their views by private communication' (RGW 309). The greater the majority of votes favouring one option, 'the more the general will is dominant' (CS IV.2). Bosanquet's response was that this is precisely 'the wrong method for eliminating private interests and getting at the general will' (RGW 317). As was shown earlier, this method does not allow one to distinguish between the product of a variety of irrational motives of a number of people for a certain good - a will of all - and a statement of the general will. Even if what is left over after employing Rousseau's method is an accurate expression of a common will at one point in time, the 'general character' of this will is still just, Bosanquet says, 'a coincidence or matter of chance' (RGW 309).

But if one cannot discern the general will by Rousseau's method, then how is one to do so? Here Bosanquet would point to the role played by social institutions. It was Bosanquet's belief that Rousseau feared the existence of such associations in the state because each would have its own interest separate from the common interest. This fear of sectarian conflict in the body politic, Bosanquet suggests, led Rousseau to overlook that these institutions are not only important in one's coming to awareness of the general will, but are, in fact, manifestations of this will (IPR 335; PTS 114-115). For a more complete account of the nature and function of social institutions, Bosanquet turned to Hegel's discussion of Sittlichkeit (Ethical Life) in Philosophy of Right.

Following Hegel, Bosanquet argues that the state and its related institutions (e.g., family, neighbourhood, social class, etc.) are the external manifestations of the system of dominant ideas in society. '[M]inds and society are really the same fabric regarded from different points of view... Every social group is the external aspect of a set of corresponding mental systems in individual minds' (PTS 158-159). As expressions of the general will, these institutions reflect the content of this will and 'aim' at the realization of the common good. Specifically, they provide a concrete indication of the requirements of morality, and serve as mechanisms by which the activity of individuals (and society as a whole) is protected and directed towards the common good.

It is not necessary - indeed, Bosanquet would say it is not possible - that laws and social institutions perfectly mirror the general will. 
Nevertheless, the will expressed in these institutions is still 'more complete than the explicit ideas which, at any given instant, move any individual mind in volition' (PTS 115). Social institutions function, so to speak, as 'the standing interpretation of all the private wills' that compose them (PTS 115), and individuals may (Rousseau's suspicions of associations in the state notwithstanding) refer to them in order to have some indication of what the general will demands. Of course, no one ought to mistake the 'will' of any one of these institutions for the general will. Bosanquet recognizes, as well, the threat to true sovereignty, foreseen by Rousseau, that would occur if a particular will (of an individual or of a group), rather than the general will, should become dominant (IPR 335, n. 2). In wishing to avoid these consequences, however, it does not follow that one need deny the role of such institutions as expressions of the general will.

One must not forget, moreover, that discussion and social interchange are natural to social life and that it is through this give-and-take that the ideas dominant in society gradually become recognized as such. Yet, as pointed out earlier, not only does this process of recognition allow people to become more conscious of what the general will is, but it leads to the establishment of social institutions and practices which, themselves, reflect the general will. Activity in formal and informal associations, and in social institutions and social practices is essential in the discernment of the general will and, as well, is a necessary part of life in society.

Bosanquet concludes, then, that the best indication of the general will in a society - though it is by no means infallible - is provided by the characteristics of, and the forces at work in, social institutions. In the end, however, the question for Bosanquet - and, he seems to suggest, for Rousseau as well - is not so much whether social institutions and society as a whole serve as indicators of the general will but, rather, how far they do.

Although Bosanquet's account of the general will differs from Rousseau's in the respects signaled above, its guiding principles still remain within that tradition. This seems particularly clear in his explanation of the role of the general will in moral and political obligation and in political freedom and in his analysis of the general character of the general will. In each case, the argument Bosanquet provides is essentially that of Rousseau.

Like Rousseau, Bosanquet maintains that only the will of the individual has a moral authority over his actions. Since the general will is, putatively, the real and true will of the individual - not to mention that it reflects knowledge and rationality greater than that possessed by any particular individual - Bosanquet argues that it can make a legitimate 
and 'imperative' (PTS lvi) claim on him. Given that the same argument can also be made for every other individual, the general will - by definition, the same will - is imperative on everyone. In short, it constitutes the norm and the criterion of morality and, as such, functions as a source of moral guidance for the individual (PTS 208). It is only because there is a general will, then, that one can possibly engage in moral action. ${ }^{27}$

From here it is a simple step to understanding the role of the general will in political obligation. Since the general will has moral authority over an individual's actions, its agents also have this authority. The general will serves, then, as the basis of the authority of the state. So far as the state reflects this will and aims at the common good, then, it can legitimately demand or require the individual's obedience. 'Any system of institutions which represents to us, on the whole, the conditions essential to affirming such a will... has an imperative claim upon our loyalty' (PTS 139). Indeed, given its relation to the general will, Bosanquet believes that the state may, legitimately, permit 'with the moral approval of all what the explicit theory of scarcely one will morally justify. ${ }^{28}$ The individual must obey, even if these demands are incompatible with that person's particular will or with the will of all (i.e., public opinion), since the general will is nothing more than his own authoritative will.

Given the agreement in their respective accounts of moral and political obligation, one can see how both come to essentially the same conclusion on the nature of freedom. Again, like Rousseau, Bosanquet denies that the state or the general will limits one's freedom; it is, rather, 'the embodiment of our liberty' (PTS 139). Rousseau sees 'moral freedom' as acquired only in the civil state (CS I.8, p. 56), and Bosanquet insists that the state is 'the main organ and condition of... liberty' (PTS 127). Indeed, both Bosanquet and Rousseau agree that the very definition of the word 'liberty' hinges on the existence of the general will. It is only by reference to this will that one can distinguish liberty (where an individual is subject to the general will) from licence (where he is subject only to his particular will). ${ }^{29}$ This definition allows Bosanquet to conclude with Rousseau that, when one's private will conflicts with the general will, he can be forced by this general will to obey it - that is 'forced to be free' (PTS 90; CS I.7).

The importance of Rousseau's influence on Bosanquet is also apparent when it comes to the question of how the general will is 'general.' Even though Bosanquet's notion of the general will is that of an 'idea force' - that is, of the system of dominant ideas at work in society this will has essentially the same characteristics as those to which Rousseau refers. 
Bosanquet holds, for example, that the general will has its source in the wills of all the members of a social group and, hence, is general in origin. ${ }^{30}$ It is also general in form because, first, as the interpretation and the maximization of a particular will, it 'transcends' the individual (PTS 100). Moreover, since the same result will be arrived at by starting from any person within that group and by using the same procedure, the general will in fact 'transcends' every member of that group.

The general will is general also because it aims at an object which surpasses any private end or goal - the common interest, which Bosanquet calls 'the best life.' And it is general in content since it summarizes and expresses the wills of all the individuals in society, corrected and modified by reason and by all the information available. Finally, the general will is general in scope, because it is morally binding on, and applies equally to, all those from whom it has its source.

There is no doubt of the immense debt that Bosanquet owed to Rousseau and, from what has been shown, his remarks on the nature and origin of the general will are, in large part, an extension and elaboration of those of Rousseau. It is clear that Bosanquet agrees with much of what Rousseau has to say on the function of the general will in civil society. It is a principle of unity which pervades man's existence in community and which directs him toward his realization. It also establishes and directs the state, determines moral and civil liberty, grounds relations between individuals and explains the moral and social justification of rights.

Bosanquet's primary interest was to build on the insights that he found in Rousseau. Still, given some of the inadequacies in this account, Bosanquet felt obliged to extend Rousseau's idea of the general will in two important ways: first, he provided a metaphysical analysis of this will - an analysis on which, arguably, Rousseau's discussion of the general will itself can depend - and, second, via Hegel, he showed the importance of social institutions in its elaboration and discernment. Whether such additions in the end contribute to, or count against, Rousseau's original view is, however, a matter that must be left for another time.

WILLIAM SWEET

Saint Francis Xavier University 


\section{Notes}

1 Bosanquet's major discussion of the general will appears in the following books and articles: 'Les idées politiques de Rousseau,' (henceforth abbreviated as IPR) in Revue de métaphysique et de morale, XX (1912), pp. 321-40; The Philosophical Theory of the State, (PTS) 1st edition, 1899; 4th edition, London: 1923; 'The Reality of the General Will,' (RGW) International Journal of Ethics, IV (1893 - 1894), pp. 308-321 (reprinted in Aspects of the Social Problem, London: 1895 and in Science and Philosophy and Other Essays by the Late Bernard Bosanquet, Eds. J.H. Muirhead and R.C. Bosanquet, London: 1927); 'The Notion of the General Will,' (NGW) Mind, n.s. XXIX (1920), pp. 77-81.

2 It would be misleading to say, then, that Rousseau is not concerned with facts in the Contrat Social. He does not give an account of how social and political institutions came to exist, but, as I shall explain later, he does think he can say what would make such institutions legitimate.

3 'La volonté, non la force, telle est la base de l'Etat' (IPR 323). This phrase no doubt comes from Nettleship's outline and table of contents of T.H. Green's Lectures on the Principles of Political Obligation (posthumously published (1886) in his Works, Volume II, pp. 307-553; reprinted, with a preface by Bosanquet, London: Longmans, Green and Co., 1917). Green was Bosanquet's teacher and mentor at Balliol College, Oxford, and Green's comments on Rousseau in these lectures (especially sections 64 to 79) clearly influenced Bosanquet.

$4 \mathrm{Du}$ Contrat Social (CS), (Paris: Flammarion, 1966). All references to the CS are to this edition and are included in the text. Where the chapter cited is particularly long, page references will be indicated.

5 Rousseau claims that 'il est nécessaire que toutes les voix soient comptées' because the general will 'doit partir de tous pour s'appliquer à tous' (CS II.4, p. 69).

6 See MacAdam, pp. 152-153, in Howard R. Cell and James I. MacAdam, Rousseau's Response to Hobbes (New York: Peter Lang, 1988). (This chapter originally appeared as an article in Dialogue, V, No. 4, 1967.) MacAdam argues correctly that, in Rousseau, the common interest is not the same as what someone is interested in - it is just what is in someone's interest.

7 See CS IV.2, p. 148: 'nul ne peut... l'assujetir sans son aveu.'

8 See, for example, MacAdam, op.cit., pp. 145-46.

9 See MacAdam, op.cit., pp. 145-46.

10 Cf. MacAdam, p. 145. MacAdam argues that the 'moral person' is, for Rousseau, a legal fiction. One should note, however, that Bosanquet did not overlook this interpretation of Rousseau although, in the end, he rejected it.

11 This reading does, then, reject MacAdam's view of the particular and general wills as 'two acts or tendencies of (the same) will' (MacAdam, op.cit., p. 145).

12 'Il fallait insister sur la réalité supérieure de quelque chose qui n'est pas un individu humain visible, mais qui est l'esprit ou la pensée sous-jacente d'un corps d'individus, pour qu'une volonté à la fois positive et générale pût être pensée' (IPR 332-333).

13 See also CS II.4, p. 68: ‘Chacun aliène par le pacte social... la partie... dont l'usage l'importe à la communauté.' 
14 While acknowledging the importance of this contribution, Hegel, in the Philosophy of Right (Grundlinien der Philosophie des Rechts [ed. Eduard Gans, Berlin: 1833]), also rejects Rousseau's notion of a general will (der gemeinschaftliche Wille), preferring instead to talk about what he calls, alternately, 'the absolute Will' (sec. 301), 'the substantial Will' (der substantielle Wille) (sec. 258), the 'universal Will' (der allgemeine Wille) and Reason - the will 'in itself and for itself' (der an und fuer sich seiende Wille, die Vernunft) (secs. 258 and 301). (Hegel's objections to Rousseau are not as detailed as those of Bosanquet. They seem to be (i) that while Rousseau formally distinguishes the general will from the will of all, in the end they are conflated and, (ii) that Rousseau fails to see that the universal Will is identical to the will of the State in law and in actually existing institutions.)

15 Indeed, Bosanquet says that Rousseau's method is 'rather adapted to a plebiscite on a single question' (RGW 309).

16 One may think of the general opinion or 'sense' that can be said to exist at a meeting. The 'sense of the meeting' exists, although not necessarily in an explicit or concrete way. It is, as it were, a summary of what has been expressed or implied, but it continues to evolve.

17 '(L)e législateur a, pour tâche...à produire l'esprit social' (IPR 336; see CS II.7).

18 'Celui qui rédige les lois n'a donc ou ne doit avoir aucun droit législatif' (CS II.7, p. 78). Though see Discours sur l'économie politique in Oeuvres complètes, Vol. III. Bibliothèque de la Pléiade (Paris: Gallimard, 1964), p. 250: 'Je conclus donc que... le premier devoir du législateur est de conformer les lois à la volonté générale.'

19 A parallel for modern readers may be found in John Rawls' A Theory of Justice (Cambridge: Harvard U. Press, 1971), wherein Rawls discusses the formulation of a hypothetical social contract whose clauses justify what is roughly the modern social-democratic state. Rawls recognizes in his introduction his explicit debt to Rousseau, though he does not specify the nature of this debt.

20 'Qu'est-ce qui peut... rendre (ce changement) légitime?' (CS I.1).

21 Thus, Bosanquet writes that 'l'organisation, la discussion, échange d'informations et de convictions, sont la vie même de l'opinion politique, qui lorsqu'elle se cristallise et prend forme, est la volonté générale' (IPR 335).

22 This apparently contra Rousseau. The terms of the social pact are that 'chacun de nous met en commun sa personne et toute sa puissance sous la suprême direction de la volonté générale...' (CS I.6) (Emphasis mine). Indeed, in some situations, it appears that, for Bosanquet, common life must precede one's sharing in the general will of a community (see RGW 318).

23 The 'dominant ideas of persons' constitute a 'machine whose parts play into one another,' and 'the more important workings of the machine, and especially the direction of its readjustment, are the most familiar expression of the general will' (RGW 313-314).

24 Bosanquet claims that it was not simply at a common will, but at this 'will in itself' or 'real will' that Rousseau was aiming (PTS 100).

25 'The General Will seems to be...the ineradicable impulse of an intelligent being to a good extending beyond itself, in as far as that good takes the form of a common good' (PTS 102). A consequence of this, suggested by Hegel but unexplored by Rousseau, is that it eliminates the heuristic need for a social contract. 
26 Bosanquet describes this as, at best 'an irrational form of the general will' (RGW 313), although he acknowledges that 'it is definitely general insofar as it is owing to the operation of the same sentiment in all the minds at once' (RGW 313).

27 Unlike Rousseau, however, Bosanquet seems to insist that it is only because this will is a person's real will that he is worthy of the moral consideration due a person (see PTS 207). See my 'L'individu et les droits de la personne selon Maritain et Bosanquet,' in Etudes maritainiennes / Maritain Studies, VI (1990): 141-66

28 'The Function of the State in Promoting the Unity of Mankind,' in Social and International Ideals (1917; reprinted New York, 1967), p. 274, quoting F.H. Bradley, Ethical Studies, (2d. edition (1927), p. 184). Bosanquet says that if we all understood our own active ideas completely and rightly in relation to those of others, then we should have the whole general will in our explicit consciousness' (RGW 316). Of course, 'no individual can ever have this' (RGW; see PTS 112), and so he may never fully understand why what he is being forced to do is really the accomplishment of his freedom. For Rousseau, just as much as Bosanquet, it would be difficult, if not impossible, for an individual to arrive at a precise formulation of the general will.

29 See CS I.8, pp. 55-56: 'il faut bien distinguer la liberté naturelle qui n'a pour bornes que les forces de l'individu, de la liberté civile qui est limitée par la volonté générale.'

30 Bosanquet is not saying just that this gives us the same 'raw data' from which we can construct the general will, but that there is a logical continuum from the individual will to the development of the general will. 